\title{
Changes in soil properties and erodibility of gully heads induced by vegetation restoration on the Loess Plateau, China
}

\author{
GUO Mingming ${ }^{1}$, WANG Wenlong ${ }^{1,2 *}$, KANG Hongliang ${ }^{1}$, YANG Bo ${ }^{1}$ \\ ${ }^{1}$ State Key Laboratory of Soil Erosion and Dryland Farming on the Loess Plateau, Institute of Soil and Water Conservation, \\ Northwest A\&F University, Yangling 712100, China; \\ ${ }^{2}$ Institute of Soil and Water Conservation, Chinese Academy of Sciences and Ministry of Water Resources, Yangling 712100 , \\ China
}

\begin{abstract}
Soil erosion on the Loess Plateau of China is effectively controlled due to the implementation of several ecological restoration projects that improve soil properties and reduce soil erodibility. However, few studies have examined the effects of vegetation restoration on soil properties and erodibility of gully head in the gully regions of the Loess Plateau. The objectives of this study were to quantify the effects of vegetation restoration on soil properties and erodibility in this region. Specifically, a control site in a slope cropland and 9 sites in 3 restored land-use types (5 sites in grassland, 3 in woodland and 1 in shrubland) in the Nanxiaohegou watershed of a typical gully region on the Loess Plateau were selected, and soil and root samples were collected to assess soil properties and root characteristics. Soil erodibility factor was calculated by the Erosion Productivity Impact Calculator method. Our results revealed that vegetation restoration increased soil sand content, soil saturated hydraulic conductivity, organic matter content and mean weight diameter of water-stable aggregate but decreased soil silt and clay contents and soil disintegration rate. A significant difference in soil erodibility was observed among different vegetation restoration patterns or land-use types. Compared with cropland, soil erodibility decreased in the restored lands by $3.99 \%$ to $21.43 \%$. The restoration patterns of Cleistogenes caespitosa K. and Artemisia sacrorum L. in the grassland showed the lowest soil erodibility and can be considered as the optimal vegetation restoration pattern for improving soil anti-erodibility of the gully heads. Additionally, the negative linear change in soil erodibility for grassland with restoration time was faster than those of woodland and shrubland. Soil erodibility was significantly correlated with soil particle size distribution, soil disintegration rate, soil saturated hydraulic conductivity, water-stable aggregate stability, organic matter content and root characteristics (including root average diameter, root length density, root surface density and root biomass density), but it showed no association with soil bulk density and soil total porosity. These findings indicate that although vegetation destruction is a short-term process, returning the soil erodibility of cropland to the level of grassland, woodland and shrubland is a long-term process (8-50 years).
\end{abstract}

Keywords: soil erosion; land use; soil properties; revegetation; root characteristics; headcut retreat; Loess Plateau

Citation: GUO Mingming, WANG Wenlong, KANG Hongliang, YANG Bo. 2018. Changes in soil properties and erodibility of gully heads induced by vegetation restoration on the Loess Plateau, China. Journal of Arid Land, 10(5): 712-725. https://doi.org/10.1007/s40333-018-0121-z

\footnotetext{
*Corresponding author: WANG Wenlong (E-mail: nwafu_wwl@163.com)

Received 2017-07-21; revised 2017-11-21; accepted 2018-02-05

(C) Xinjiang Institute of Ecology and Geography, Chinese Academy of Sciences, Science Press and Springer-Verlag GmbH Germany, part of Springer Nature 2018
} 


\section{Introduction}

In the past several decades, soil erosion on the Loess Plateau of China has led to severe losses of soil and fertility, resulting in a serious problem of regional food security (Wang et al., 2013). In particular, approximately $63 \%$ of total runoff in the gully regions of the Loess Plateau is generated from loess tableland, which initiates gully headward erosion and contributes to $86 \%$ of total sediment. A gully head refers to a sudden step change in a gully channel bed, in which intense erosion occurs due to concentrated flow scouring from the loess tableland area (upstream area) (Bennett and Alonso, 2006). A series of research programs have been conducted in the gully regions of the Loess Plateau to control the gully headward erosion. Most importantly, conversion of sloped cropland to land with restored vegetation results in great changes in vegetation in a short period, and this has been proposed as an effective measure for controlling soil and water loss, which attributed to improvements in soil properties and reductions in soil erodibility (Huang et al., 2010; Wang et al., 2013; Wu et al., 2016). Generally speaking, sloped croplands are increasingly being restored to control soil loss. In the gully regions of the Loess Plateau, croplands close to gully heads have also been restored to restrain gully headward erosion. As important soil quality indicators, soil properties are frequently employed to assess the benefits of altered land use with vegetation restoration (Wang et al., 2012; Zhang et al., 2013; Wu et al., 2016). Soil erodibility, which is the susceptibility of soil to erosion, is a critical factor used to estimate the soil erosion rate and to plan soil and water conservation measures (Singh and Khera, 2008; Wang et al., 2013). Hence, the investigation of changes in soil erodibility and properties of gully heads induced by vegetation restoration is important for reasonably planning vegetation measures in the gully head areas.

Some studies concluded that vegetation restoration causes changes in soil properties, such as soil bulk density and soil total porosity (Li and Shao, 2006; Zhang et al., 2013), soil infiltration (Wang et al., 2013; Zhao et al., 2013), soil saturated hydraulic conductivity (Li and Shao, 2006; Hu et al., 2009; Wu et al., 2016), water-stable aggregate stability (Li and Shao, 2006; Wang et al., 2012; Zhang et al., 2013), and soil erodibility (Parwada and Tol, 2016), as well as other properties (Jiao et al., 2011). On the Loess Plateau, soil bulk density decreases, and the contents of soil organic matter $(\mathrm{SOM})$ and macroaggregates $(>0.25 \mathrm{~mm})$ and aggregate stability increase across a chronosequence of naturally restored vegetation (Li and Shao, 2006; An et al., 2009; Jiao et al., 2011). Root activity, the development of biopores and improvement in aggregate stability resulting from re-conversion of cropland to grassland alter soil hydraulic conductivity, with a great effect on infiltration capacity and water movement in soil (Schwartz et al., 2003). However, different conclusions have been reached for changes in soil infiltration with restoration time. For example, Zhu et al. (2010) reported that soil erodibility linearly decreased as the abandonment period increased. However, Wang et al. (2013) suggested that soil erodibility of natural abandoned cropland decreased gradually with restoration time and tended to stabilize by 28 years after abandonment. These differences indicate that changes in soil properties and erodibility exhibit diverse patterns during vegetation succession in different study regions. Therefore, the changes in soil properties and erodibility of gully heads after re-conversion of cropland to land with restored vegetation require further investigation.

In general, changes in soil erodibility during vegetation restoration are induced by complex interactions between soil properties and root characteristics (De Baets et al., 2006). Knapen et al. (2007) and Zhu et al. (2010) revealed that soil erodibility decreases as soil bulk density increases. Sheridan et al. (2000) reported a negative relationship between soil erodibility and clay content, whereas no significant correlation was found by Li et al. (2015). Water-stable macroaggregates have a negative effect on soil erodibility (Barthès and Roose, 2002), and soil erodibility is effectively weakened (Knapen et al., 2008) because SOM can promote the development of soil aggregates. Significant negative correlations have been found between soil erodibility and steady infiltration rate and between soil erodibility and disintegration rate (Li et al., 2015; Wang et al., 2015). Furthermore, the root system of vegetation plays an important role in controlling soil erosion via effects of physical binding and chemical bonding to increase soil stability and 
resistance to erosion. In some studies, rill soil erodibility was observed to decrease exponentially with increasing root biomass density or length density (Mamo and Bubenzer, 2001a, b; Gyssels et al., 2005; De Baets et al., 2006; Zhang et al., 2013). Moreover, vegetation and soil properties are the primary factors controlling the resistance of gully heads to erosion (Vanmaercke et al., 2016). Most studies to date on gully headward erosion have been conducted using aerial photographs (Marzolff and Poesen, 2009), field surveys (Frankl et al., 2012) and three-dimensional reconstruction technology based on photos (Gómez-Gutiérrez et al., 2014). However, given the difficulties in measuring belowground biomass characteristics, such as root (length, surface area, and biomass) density using the above mentioned methods, relatively few data on the effects of root systems on soil erodibility of gully heads are available (Vannoppen et al., 2015), particularly on the Loess Plateau. Therefore, the effect of changes in soil properties and root characteristics on soil erodibility during a long-term conversion of cropland to restored lands requires further investigation.

To better evaluate the efficiency of vegetation restoration, the impacts of land-use change and patterns of vegetation restoration on soil properties and erodibility of gully heads over time should be determined. In this study, we assumed that soils from 10 croplands in a typical gully region of the Loess Plateau before restoration had the same spatial textural homogeneity and followed the same underlying mechanisms during restoration. The objective of this study was to identify changes in soil properties and erodibility of gully heads associated with 4 land-use types and 9 vegetation restoration patterns as well as the relationships between soil erodibility and influencing factors.

\section{Materials and methods}

\subsection{Study area}

The study was conducted in the Nanxiaohegou watershed of the Xifeng Research Station of Soil and Water Conservation $\left(35^{\circ} 41^{\prime}-35^{\circ} 44^{\prime} \mathrm{N}, 107^{\circ} 30^{\prime}-107^{\circ} 37^{\prime} \mathrm{E}\right.$; $1050-1423 \mathrm{~m}$ a.s.l.; Fig. 1), located in a typical gully region of the Loess Plateau, China. The watershed has an area of $36.3 \mathrm{~km}^{2}$. The study area is characterized by a temperate continental semiarid climate. The annual mean temperature is $10^{\circ} \mathrm{C}$, and the frost-free period is $160-180 \mathrm{~d}$. Annual precipitation is approximately $523 \mathrm{~mm}$, with $58.8 \%$ of the total precipitation occurring between July and September in the form

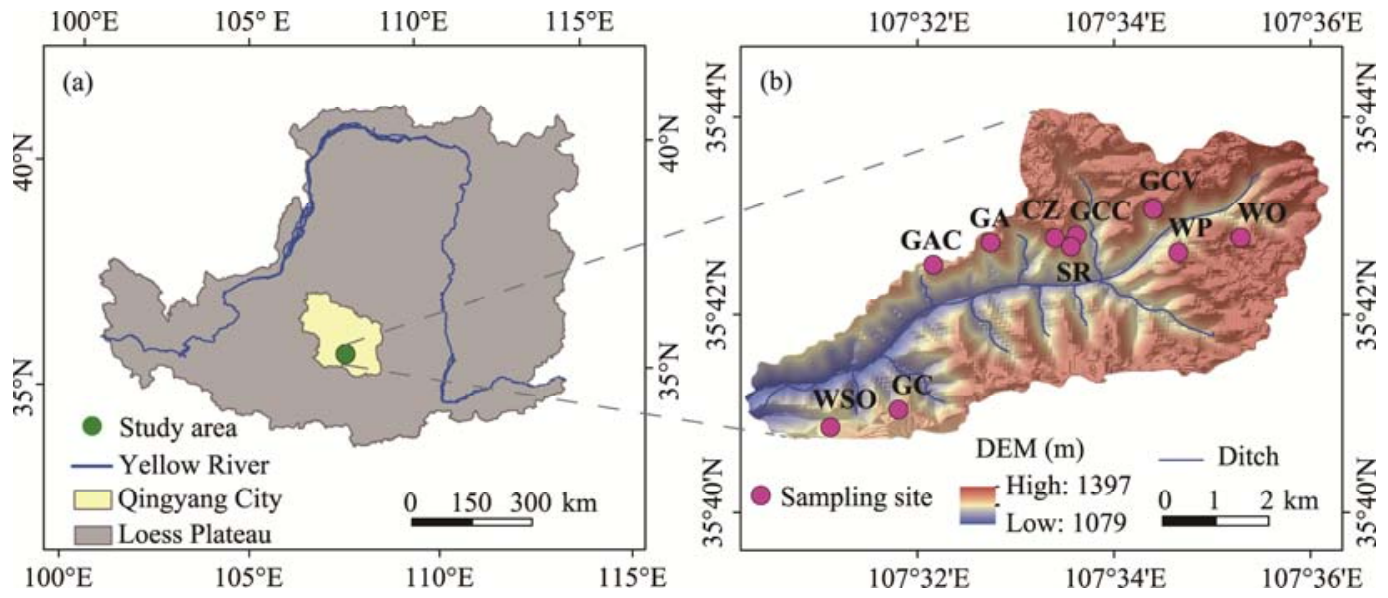

Fig. 1 Location of the study area (Nanxiaohegou watershed) (a) and distribution of the sampling sites (b). DEM, Digital Elevation Model; CZ, slope cropland of Zea mays L.; GA, grassland community of Artemisia annua L.; GAC, mixed grassland community of A. annua and Agropyron cristatum (L.) Gaertn.; GC, grassland community of A. cristatum; GCC, mixed grassland community of A. cristatum and Cleistogenes caespitosa K.; GCV, mixed grassland community of $C$. caespitosa and Artemisia vestita Wall. ex Bess; WP, black locust woodland of Robinia pseudoacacia L.; WO, cypress woodland of Platycladus orientalis (L.) Franco; WSO, mixed woodland of Armeniaca sibirica (L.) Lam and Acer oliverianum Pax; SR, shrubland of Hippophae rhamnoides L. 
of short heavy rain storms. The soil type is silt loam soil. The original vegetation has disappeared due to human activities. In recent decades, soil and water loss has been effectively controlled due to the implementation of vegetation restoration projects. At present, the vegetation types primarily include the planted forests and shrubs, and native secondary herbaceous plant communities.

\subsection{Experimental design, sampling and measurements}

The study was conducted from June to August 2016. We selected a control site in a slope cropland (CZ, slope cropland of Zea mays L.) and 9 sites in 3 restored land-use types, including 5 sites in grassland (GA, the grassland community of Artemisia annua L.; GAC, the mixed grassland community of Agropyron cristatum (L.) Gaertn. and A. annua.; GC, the grassland community of A. cristatum; GCC, the mixed grassland community of A. cristatum and Cleistogenes caespitosa $\mathrm{K}$.; GCV, the mixed grassland community of C. caespitosa and Artemisia vestita Wall. ex Bess), 3 in woodland (WP, the black locust woodland of Robinia pseudoacacia L.; WO, the cypress woodland of Platycladus orientalis (L.) Franco; WSO, the mixed woodland of Armeniaca sibirica (L.) Lam and Acer oliverianum Pax) and 1 in shrubland (SR, the shrubland of Hippophae rhamnoides L.) based on a detailed investigation of land uses and vegetation community types in some typical gully heads (Fig. 1; Table 1). It should be noted that we selected the sites with similar slope aspect, slope gradient, elevation, soil type and previous farming practices to minimize effects on the results. Further, we selected 5 typical grass communities as representative grassland according to the natural successional process of grass vegetation. The primary planted woodland types were $R$. pseudoacacia, Platycladus orientalis (L.) Franco and mixed forest of $A$. sibirica and A. oliverianum. Because of the intense human activity, few shrubs were present in the study area, and the typical shrub tree is $H$. rhamnoides.

Table 1 Land-use type, vegetation, topography and restoration time for the selected sites

\begin{tabular}{|c|c|c|c|c|c|c|}
\hline Land-use type & Site & Dominant plant species & $\begin{array}{c}\text { Coverage } \\
(\%)\end{array}$ & $\begin{array}{c}\text { Slope } \\
(\%)\end{array}$ & $\begin{array}{c}\begin{array}{c}\text { Elevation } \\
(\mathrm{m})\end{array} \\
\end{array}$ & $\begin{array}{c}\text { Restoration } \\
\text { time (a) }\end{array}$ \\
\hline Cropland & $\mathrm{CZ}$ & Zea mays L. & 56 & 5.23 & 1351 & 1 \\
\hline \multirow[t]{5}{*}{ Grassland } & GA & Artemisia annua $\mathrm{L}$. & 45 & 6.98 & 1280 & 3 \\
\hline & GAC & A. annua. +Agropyron cristatum (L.) Gaertn. & 65 & 5.58 & 1277 & 4 \\
\hline & GC & A. cristatum & 50 & 7.32 & 1280 & 7 \\
\hline & GCC & A. cristatum +Cleistogenes caespitosa $\mathrm{K}$. & 92 & 5.06 & 1287 & 8 \\
\hline & GCV & C. caespitosa. + Artemisia vestita Wall. ex Bess & 90 & 9.41 & 1289 & 17 \\
\hline \multirow[t]{3}{*}{ Woodland } & WP & Robinia pseudoacacia L. & $54^{*}$ & 10.80 & 1278 & 25 \\
\hline & WO & Platycladus orientalis (L.) Franco & $84^{*}$ & 9.24 & 1273 & 40 \\
\hline & WSO & Armeniaca sibirica (L.) Lam+Acer oliverianum Pax & $65^{*}$ & 5.93 & 1260 & 35 \\
\hline Shrubland & $\mathrm{SR}$ & Hippophae rhamnoides L. & $86^{*}$ & 4.88 & 1275 & $38^{\#}$ \\
\hline
\end{tabular}

Note: CZ, slope cropland of Zea mays L.; GA, grassland community of Artemisia annua L.; GAC, mixed grassland community of Agropyron cristatum (L.) Gaertn. and A. annua.; GC, grassland community of A. cristatum; GCC, mixed grassland community of A. cristatum and Cleistogenes caespitosa K.; GCV, mixed grassland community of C. caespitosa and Artemisia vestita Wall. ex Bess; WP, black locust woodland of Robinia pseudoacacia L.; WO, cypress woodland of Platycladus orientalis (L.) Franco; WSO, mixed woodland of Armeniaca sibirica (L.) Lam and Acer oliverianum Pax; SR, shrubland of Hippophae rhamnoides L. ${ }^{*}$ indicates grass coverage under the forest. " indicates that the restoration time of shrubland was approximately 38 years.

Three sampling plots of $5 \mathrm{~m} \times 5 \mathrm{~m}$ were established for soil and root sampling at each study site. The soil particle size distribution, soil bulk density, soil total porosity, soil disintegration rate, soil saturated hydraulic conductivity, water-stable aggregate stability and root characteristics were measured. For each study site, 15 soil samples ( 3 sampling plots $\times 5$ soil samples/per plot) for each soil property parameter were collected from the top $20 \mathrm{~cm}$ of soil in a "S"-shaped pattern. Steel cutting rings $\left(100 \mathrm{~cm}^{3}\right)$ were collected from the top $20 \mathrm{~cm}$ of soil, and each steel ring was weighed after drying for $24 \mathrm{~h}$ at $105^{\circ} \mathrm{C}$ to determine the soil bulk density and soil total porosity, assuming a soil particle density of $2.65 \mathrm{~g} / \mathrm{cm}^{3}$. Fifteen soil samples obtained using a cubical iron box ( $5 \mathrm{~cm}$ in length) at each site were employed to measure the soil disintegration rate using the soil disintegrating box developed following the float barrel principle (Li et al., 2015). For each site, 15 soil samples obtained using a steel cutting ring $\left(200 \mathrm{~cm}^{3}\right)$ were saturated and measured 
under a constant head to assess the soil saturated hydraulic conductivity by the constant head method (Wang et al., 2012). The soil particle distribution was measured using a MasterSizer 2000 laser sizer (Malvern Instruments Ltd., Malvern, UK). Sieves with different apertures $(0.25,0.50$, $1.00,2.50$ and $5.00 \mathrm{~mm}$ ) were used to evaluate the water-stable aggregates. A saturated soil sample of $50 \mathrm{~g}$ was placed on the sieves and then immersed into water and shaken up and down 30 times within $1 \mathrm{~min}$. The aggregates left on each sieve were weighed, and the percentage of each class was calculated (Wang et al., 2014). The mean weight diameter, an indicator of of water-stable aggregate stability across the range of aggregate classes, was calculated from the dried mass of the aggregates left on each sieve (Bissonnais, 1996). The potassium dichromate external heating method was used to measure the SOM content. A steel cubical box $(10 \mathrm{~cm}$ in length) was used to collect 5 soil samples from each sampling plot. These samples were combined and soaked in tap water for approximately $1 \mathrm{~h}$ to increase the soil dispersion, and the samples were placed on a $0.25-\mathrm{mm}$ sieve and washed with tap water using a low-pressure head. Living roots, plant debris and some pebbles remained on the sieve. Only the living roots were carefully retrieved using tweezers (Yu et al., 2014) and then scanned using an Epson V700 scanner (Seiko Epson Corporation, Nagano Prefecture, Japan) at a resolution of 300 dpi. Root characteristics were measured using Win RHIZO image analysis software (version 2007 pro) to obtain the root average diameter, root length density, and root surface area density. The roots were oven-dried for $24 \mathrm{~h}$ at $65^{\circ} \mathrm{C}$ and weighed to calculate the root biomass density. The soil erodibility factor $(K)$ was calculated by the Erosion Productivity Impact Calculator (EPIC) method using Equation 1 (Williams and Arnold, 1997).

$$
\begin{aligned}
& K=\{0.2+0.3 \exp [-0.0256 \mathrm{SAN}(1-\mathrm{SIL}) / 100]\} \times\left(\frac{\mathrm{SIL}}{\mathrm{CLA}+\mathrm{SIL}}\right)^{0.3} \\
& \times\left[1.0-\frac{0.25 \mathrm{C}}{\mathrm{C}+\exp (3.72-2.95 \mathrm{C})}\right] \times\left[1.0-\frac{0.7 \mathrm{SN}_{1}}{\mathrm{SN}_{1}+\exp \left(-5.51+22.95 \mathrm{SN}_{1}\right)}\right]
\end{aligned}
$$

where SAN (\%) is the sand content $(2.000-0.050 \mathrm{~mm})$; SIL (\%) is the silt content $(0.050-0.002$ $\mathrm{mm})$; CLA (\%) is the clay content $(<0.002 \mathrm{~mm})$; C (\%) is the soil organic carbon (SOC) content, which can be calculated as follows: $\mathrm{SOC}$ content $=0.583 \times \mathrm{SOM}$ content; $\mathrm{SN}_{1}(\%)$ is a transition variable, $\mathrm{SN}_{1}=1-\mathrm{SAN} / 100 . K$ is expressed as a standard unit of the USA, $K=0.1317 \times$ the standard international unit $\left(\left(\mathrm{t} \cdot \mathrm{hm}^{2} \cdot \mathrm{h}\right) /\left(\mathrm{MJ} \cdot \mathrm{mm} \cdot \mathrm{hm}^{2}\right)\right)$.

\subsection{Statistical analyses}

Soil properties and erodibility were compared among land-use types and vegetation patterns using analysis of variance (ANOVA). Correlations were tested using the SPSS statistical software package (version 16.0). Duncan's test $(P<0.05)$ was used to compare the means of soil properties and erodibility when the results of ANOVA were significant at $P<0.05$ level. Regression relationships between soil erodibility and influencing factors were analyzed by a simple regression method.

\section{Results}

\subsection{Variations in soil properties after vegetation restoration}

3.1.1 Soil bulk density and soil total porosity

As shown in Table 2, the soil bulk density of cropland was $1.16 \mathrm{~g} / \mathrm{cm}^{3}$, and the average soil bulk density of grassland, woodland and shrubland was $4.31 \%, 7.76 \%$ and $2.59 \%$ greater than that of cropland, respectively. No significant difference was found among the soil bulk density values of the 3 land-use types, indicating that the soil bulk density was not affected by land uses. For the 5 sites in the grassland, the soil bulk density values of GA $\left(1.31 \mathrm{~g} / \mathrm{cm}^{3}\right)$ and $\mathrm{GC}\left(1.26 \mathrm{~g} / \mathrm{cm}^{3}\right)$ were significantly higher than those of the other 3 sites $(P<0.05)$, with the lowest soil bulk density $\left(1.12 \mathrm{~g} / \mathrm{cm}^{3}\right)$ in GCC. For woodland and shrubland, WP had the highest bulk density (1.35 
Table 2 Soil properties of the selected sites

\begin{tabular}{|c|c|c|c|c|c|c|c|c|c|}
\hline $\begin{array}{c}\text { Land-use } \\
\text { type }\end{array}$ & Site & $\begin{array}{l}\text { CLA } \\
(\%)\end{array}$ & $\begin{array}{l}\text { SIL } \\
(\%)\end{array}$ & $\begin{array}{c}\text { SAN } \\
(\%)\end{array}$ & $\begin{array}{c}\text { SBD } \\
\left(\mathrm{g} / \mathrm{cm}^{3}\right)\end{array}$ & $\begin{array}{l}\text { STP } \\
(\%)\end{array}$ & $\begin{array}{c}\text { SDR } \\
(\mathrm{g} / \mathrm{min})\end{array}$ & $\begin{array}{c}\mathrm{SHC} \\
(\mathrm{cm} / \mathrm{min})\end{array}$ & $\begin{array}{c}\text { SOM } \\
(\%)\end{array}$ \\
\hline Cropland & $\mathrm{CZ}$ & $15.72^{\mathrm{abA}}$ & $73.69^{\mathrm{aA}}$ & $10.59^{\mathrm{eC}}$ & $1.16^{\mathrm{deA}}$ & $56.04^{\mathrm{Aab}}$ & $2.34^{\mathrm{aA}}$ & $0.05^{\mathrm{cA}}$ & $0.36^{\mathrm{eC}}$ \\
\hline \multirow[t]{6}{*}{ Grassland } & GA & $14.75^{\mathrm{ab}}$ & $71.61^{\mathrm{a}}$ & $13.64^{\mathrm{cd}}$ & $1.31^{\mathrm{ab}}$ & $50.69^{\mathrm{de}}$ & $1.66^{\mathrm{b}}$ & $0.03^{\mathrm{c}}$ & $0.76^{\mathrm{d}}$ \\
\hline & GAC & $15.12^{\mathrm{ab}}$ & $73.03^{\mathrm{a}}$ & $11.85^{\mathrm{de}}$ & $1.21^{\mathrm{cd}}$ & $54.44^{\mathrm{bc}}$ & $1.17^{\mathrm{b}}$ & $0.06^{\mathrm{c}}$ & $0.66^{\mathrm{d}}$ \\
\hline & GC & $15.20^{\mathrm{ab}}$ & $71.75^{\mathrm{a}}$ & $13.05^{\text {cde }}$ & $1.26^{\mathrm{bc}}$ & $52.48^{\mathrm{cd}}$ & $1.59^{\mathrm{b}}$ & $0.10^{\mathrm{bc}}$ & $0.85^{\text {cd }}$ \\
\hline & GCC & $14.62^{\mathrm{ab}}$ & $69.52^{\mathrm{a}}$ & $15.86^{\mathrm{bc}}$ & $1.12^{\mathrm{e}}$ & $57.66^{\mathrm{a}}$ & $0.54^{\mathrm{c}}$ & $0.11^{\mathrm{bc}}$ & $1.02^{\mathrm{bc}}$ \\
\hline & GCV & $14.70^{\mathrm{ab}}$ & $67.88^{\mathrm{a}}$ & $17.42^{\mathrm{ab}}$ & $1.15^{\mathrm{de}}$ & $56.45^{\mathrm{ab}}$ & $0.28^{\mathrm{c}}$ & $0.15^{\mathrm{ab}}$ & $1.36^{\mathrm{a}}$ \\
\hline & Mean & $14.88^{\mathrm{A}}$ & $70.76^{\mathrm{B}}$ & $14.36^{\mathrm{B}}$ & $1.21^{\mathrm{A}}$ & $54.34^{\mathrm{A}}$ & $1.05^{\mathrm{B}}$ & $0.09^{\mathrm{A}}$ & $0.92^{\mathrm{B}}$ \\
\hline \multirow[t]{4}{*}{ Woodland } & WP & $14.03^{\mathrm{abc}}$ & $72.69^{a}$ & $13.28^{\text {cde }}$ & $1.35^{\mathrm{a}}$ & $49.08^{\mathrm{e}}$ & $0.31^{\mathrm{c}}$ & $0.05^{\mathrm{c}}$ & $0.97^{\text {bc }}$ \\
\hline & WO & $13.62^{b c}$ & $68.86^{\mathrm{a}}$ & $17.52^{\mathrm{ab}}$ & $1.18^{\text {cde }}$ & $55.32^{\mathrm{abc}}$ & $0.30^{\mathrm{c}}$ & $0.21^{\mathrm{a}}$ & $1.16^{\mathrm{b}}$ \\
\hline & WSO & $12.34^{\mathrm{cd}}$ & $70.14^{\mathrm{a}}$ & $17.52^{\mathrm{ab}}$ & $1.21^{\mathrm{cd}}$ & $54.18^{b c}$ & $0.29^{\mathrm{c}}$ & $0.16^{\mathrm{ab}}$ & $1.15^{\mathrm{b}}$ \\
\hline & Mean & $13.33^{\mathrm{B}}$ & $70.56^{\mathrm{B}}$ & $16.11^{\mathrm{B}}$ & $1.25^{\mathrm{A}}$ & $52.86^{\mathrm{A}}$ & $0.30^{\mathrm{C}}$ & $0.14^{\mathrm{A}}$ & $1.11^{\mathrm{AB}}$ \\
\hline Shrubland & SR & $11.14^{\mathrm{dC}}$ & $69.46^{\mathrm{aB}}$ & $19.40^{\mathrm{aA}}$ & $1.19^{\text {cdeA }}$ & $55.05^{\text {Aabc }}$ & $0.26^{\mathrm{cC}}$ & $0.10^{\text {bcA }}$ & $1.36^{\mathrm{aA}}$ \\
\hline
\end{tabular}

Note: CLA, clay content; SIL, silt content; SAN, sand content; SBD, soil bulk density; STP, soil total porosity; SDR, soil disintegration rate; SHC, soil saturated hydraulic conductivity; SOM, soil organic matter. Different lowercase letters and capital letters in the same column indicate significant difference among different sites in the same land-use type and among different land-use types at $P<0.05$ level, respectively.

$\mathrm{g} / \mathrm{cm}^{3}$ ), with no significant difference with the other sites. Similarly, land uses had no significant effect on soil total porosity (Table 2). Among the 10 sites, the highest soil total porosity (57.66\%) was in GCC and the lowest (49.08\%) in WP. The soil total porosity values of GA, GC and WP were $9.55 \%, 6.35 \%$ and $12.42 \%$ higher than that of $\mathrm{CZ}$, respectively.

\subsubsection{Soil particle size distribution}

The sand content was significantly lower in the cropland than in the grassland, woodland and shrubland, whereas the silt content in cropland was significantly higher than those in the other land-use types (Table 2). The clay content of cropland was significantly greater than those of woodland and shrubland $(P<0.05)$, but no significant difference was found between cropland and grassland $(P>0.05)$. Among the 10 sites, SR had the lowest clay content $(11.14 \%)$, which was significantly lower than those in all other sites, except for WSO $(P<0.05)$. No significant difference in silt content was detected among all the sites $(P>0.05)$.

\subsubsection{Soil disintegration rate}

The soil disintegration rate of cropland $(2.34 \mathrm{~g} / \mathrm{min})$ was significantly larger than those of the other 3 land-use types $(P<0.05$; Table 2$)$. Furthermore, no significant difference of soil disintegration rate was found between woodland and shrubland $(P>0.05)$. For the 5 sites in the grassland, soil disintegration rates of GCC and GCV were 0.54 and $0.28 \mathrm{~g} / \mathrm{min}$, respectively, which were significantly lower than those of the other 3 sites. The soil disintegration rates in the 3 sites of woodland and 1 site of shrubland showed little difference $(0.26-0.31 \mathrm{~g} / \mathrm{min})$.

\subsubsection{Soil saturated hydraulic conductivity}

No significant difference in soil saturated hydraulic conductivity was found among the 4 land-use types $(P>0.05$; Table 2$)$. The soil saturated hydraulic conductivity values of grassland, woodland and shrubland were 1.8-, 2.8- and 2.0-fold greater than that of cropland, respectively. Except for GA, the soil saturated hydraulic conductivity values of sites in the grassland were higher than that $(0.05 \mathrm{~cm} / \mathrm{min})$ of $\mathrm{CZ}$, and soil saturated hydraulic conductivity in GCV was highest $(0.15$ $\mathrm{cm} / \mathrm{min})$ and 5 -fold higher than that in $\mathrm{CZ}(P<0.05)$. For the 3 sites in the woodland, the soil saturated hydraulic conductivity values of WO and WSO were 4.2 and 3.2 times greater than that of $\mathrm{CZ}$, respectively $(P<0.05)$.

\subsubsection{SOM content}

The SOM content values of grassland, woodland and shrubland were 2.56-, 3.08- and 3.78-fold greater than that of cropland, respectively $(P<0.05$; Table 2$)$. The results illustrated that the conversion of cropland to lands with restored vegetation enhances the accumulation of plant litter 
and roots in soil. The SOM content of GCV (1.36\%) was close to that of SR and significantly greater than those of the other sites in the grassland. However, the change in the SOM content was slight among the 3 sites in the woodland.

\subsubsection{Water-stable aggregate stability}

Vegetation restoration had significant effects on the size distribution and stability of water-stable aggregates (Table 3). The proportion of macroaggregates $(>0.25 \mathrm{~mm})$ in the woodland and shrubland increased significantly by $68.95 \%$ and $89.61 \%$, respectively, compared with that in the cropland, and there was no significant difference among woodland, shrubland and grassland. Additionally, no significant differences were found in the proportion of each size class of aggregates between woodland and shrubland. Compared with $\mathrm{CZ}$, significant increases in aggregates $(>5.00,5.00-2.00,2.00-1.00$ and $<0.25 \mathrm{~mm})$ were found in GCV site in the grassland, and the other 4 sites showed a non-significant increase in all size classes of aggregates, except for $1.00-0.50 \mathrm{~mm}$. Compared with the cropland, aggregates with size $>0.50 \mathrm{~mm}$ increased while aggregates with size $<0.25 \mathrm{~mm}$ decreased significantly in the woodland and shrubland $(P<0.05)$.

Additionally, vegetation restoration had a significant effect on the mean weight diameter of water-stable aggregate $(P<0.05)$. Mean weight diameter values of water-stable aggregate in the woodland and shrubland were 2.12- and 2.36-fold greater than that of the cropland, respectively, with no significant difference between grassland and cropland. The trend for variation in mean weight diameter and macroaggregate $(>0.25 \mathrm{~mm})$ content of water-stable aggregate was similar. In the grassland, the mean weight diameter of water-stable aggregate of GCV was $1.12 \mathrm{~mm}$, which was significantly greater than those of the other 4 sites. The mean weight diameter of water-stable aggregate of WP was significantly lower than those of WO, WSO and SR $(P<0.05)$.

Table 3 Percentage of water-stable aggregates with different size classes and mean weight diameter (MWD) of water-stable aggregate in the selected sites

\begin{tabular}{|c|c|c|c|c|c|c|c|c|c|}
\hline \multirow{2}{*}{$\begin{array}{l}\text { Land-use } \\
\text { type }\end{array}$} & \multirow[b]{2}{*}{ Site } & \multicolumn{7}{|c|}{ Percentage of water-stable aggregates $(\%)$} & \multirow{2}{*}{$\begin{array}{l}\text { MWD } \\
(\mathrm{mm})\end{array}$} \\
\hline & & $\begin{array}{c}>5.00 \\
\mathrm{~mm}\end{array}$ & $\begin{array}{c}2.00-5.00 \\
\mathrm{~mm}\end{array}$ & $\begin{array}{c}1.00-2.00 \\
\mathrm{~mm}\end{array}$ & $\begin{array}{c}0.50-1.00 \\
\mathrm{~mm}\end{array}$ & $\begin{array}{c}0.25-0.50 \\
\mathrm{~mm}\end{array}$ & $\begin{array}{c}<0.25 \\
\mathrm{~mm}\end{array}$ & $\begin{array}{c}>0.25 \\
\mathrm{~mm}\end{array}$ & \\
\hline Cropland & $\mathrm{CZ}$ & $6.43^{\mathrm{cB}}$ & $1.48^{\mathrm{dB}}$ & $1.36^{\mathrm{dB}}$ & $5.03^{\mathrm{cB}}$ & $21.43^{\mathrm{abcA}}$ & $64.28^{\mathrm{aA}}$ & $35.72^{\mathrm{cC}}$ & $0.58^{\mathrm{dB}}$ \\
\hline \multirow[t]{6}{*}{ Grassland } & GA & $6.54^{\mathrm{c}}$ & $1.77^{\mathrm{d}}$ & $1.52^{\mathrm{d}}$ & $13.72^{\mathrm{a}}$ & $18.94^{\mathrm{abc}}$ & $57.52^{\mathrm{ab}}$ & $42.48^{\mathrm{bc}}$ & $0.64^{\mathrm{cd}}$ \\
\hline & GAC & $7.63^{\mathrm{bc}}$ & $2.10^{\mathrm{d}}$ & $4.67^{\mathrm{d}}$ & $11.13^{\mathrm{ab}}$ & $17.84^{\mathrm{abc}}$ & $56.62^{\mathrm{ab}}$ & $43.38^{\mathrm{bc}}$ & $0.73^{\mathrm{cd}}$ \\
\hline & GC & $7.99^{\mathrm{bc}}$ & $4.16^{\mathrm{d}}$ & $5.62^{\mathrm{cd}}$ & $5.74^{\mathrm{c}}$ & $21.18^{\mathrm{abc}}$ & $55.32^{\mathrm{ab}}$ & $44.68^{\mathrm{bc}}$ & $0.78^{\mathrm{c}}$ \\
\hline & GCC & $6.10^{\mathrm{c}}$ & $5.02^{\mathrm{d}}$ & $4.69^{\mathrm{d}}$ & $5.45^{\mathrm{c}}$ & $23.77^{\mathrm{ab}}$ & $54.97^{\mathrm{ab}}$ & $45.03^{\mathrm{bc}}$ & $0.70^{\mathrm{cd}}$ \\
\hline & GCV & $9.16^{\mathrm{ab}}$ & $12.36^{\mathrm{bc}}$ & $10.43^{\mathrm{b}}$ & $6.24^{\mathrm{c}}$ & $30.31^{\mathrm{a}}$ & $31.49^{\mathrm{c}}$ & $68.51^{\mathrm{a}}$ & $1.12^{\mathrm{b}}$ \\
\hline & Mean & $7.48^{\mathrm{B}}$ & $5.08^{\mathrm{B}}$ & $5.39^{\mathrm{B}}$ & $8.46^{\mathrm{AB}}$ & $22.41^{\mathrm{A}}$ & $51.18^{\mathrm{AB}}$ & $48.82^{\mathrm{BC}}$ & $0.79^{\mathrm{B}}$ \\
\hline \multirow[t]{4}{*}{ Woodland } & WP & $9.50^{\mathrm{ab}}$ & $12.02^{\mathrm{c}}$ & $9.53^{b c}$ & $9.09^{b c}$ & $16.13^{\mathrm{abc}}$ & $43.74^{\mathrm{bc}}$ & $56.26^{\mathrm{ab}}$ & $1.10^{\mathrm{b}}$ \\
\hline & WO & $9.64^{\mathrm{ab}}$ & $19.43^{\mathrm{a}}$ & $11.46^{\mathrm{ab}}$ & $11.12^{\mathrm{ab}}$ & $7.10^{\mathrm{c}}$ & $41.25^{\mathrm{c}}$ & $58.75^{\mathrm{a}}$ & $1.30^{\mathrm{a}}$ \\
\hline & WSO & $9.61^{\mathrm{ab}}$ & $16.67^{\mathrm{abc}}$ & $14.99^{\mathrm{a}}$ & $11.67^{\mathrm{ab}}$ & $13.10^{\mathrm{bc}}$ & $33.96^{\mathrm{c}}$ & $66.04^{\mathrm{a}}$ & $1.30^{\mathrm{a}}$ \\
\hline & Mean & $9.58^{\mathrm{A}}$ & $16.04^{\mathrm{A}}$ & $12.00^{\mathrm{A}}$ & $10.63^{\mathrm{A}}$ & $12.11^{\mathrm{A}}$ & $39.65^{\mathrm{BC}}$ & $60.35^{\mathrm{AB}}$ & $1.23^{\mathrm{A}}$ \\
\hline Shrubland & SR & $10.61^{\mathrm{aA}}$ & $18.71^{\mathrm{abA}}$ & $12.69^{\mathrm{abA}}$ & $12.03^{\mathrm{abA}}$ & $13.70^{\mathrm{bcA}}$ & $32.27^{\mathrm{cC}}$ & $67.73^{\mathrm{aA}}$ & $1.37^{\mathrm{aA}}$ \\
\hline
\end{tabular}

Note: Different lowercase letters and capital letters in the same column indicate significant differences among different sites in the same land-use type and among different land-use types at $P<0.05$ level, respectively.

\subsection{Variation in soil erodibility after vegetation restoration}

The soil erodibility was significantly influenced by land uses (Fig. 2a). On average, the highest soil erodibility occurred in the cropland (soil erodibility of $0.0345\left(\mathrm{t} \cdot \mathrm{hm}^{2} \cdot \mathrm{h}\right) /\left(\mathrm{MJ} \cdot \mathrm{mm} \cdot \mathrm{hm}^{2}\right)$ ), followed by the grassland $\left(0.0312 \quad\left(\mathrm{t} \cdot \mathrm{hm}^{2} \cdot \mathrm{h}\right) /\left(\mathrm{MJ} \cdot \mathrm{mm} \cdot \mathrm{hm}^{2}\right)\right)$, woodland $(0.0297$ $\left.\left(\mathrm{t} \cdot \mathrm{hm}^{2} \cdot \mathrm{h}\right) /\left(\mathrm{MJ} \cdot \mathrm{mm} \cdot \mathrm{hm}^{2}\right)\right)$ and shrubland $\left(0.0273\left(\mathrm{t} \cdot \mathrm{hm}^{2} \cdot \mathrm{h}\right) /\left(\mathrm{MJ} \cdot \mathrm{mm} \cdot \mathrm{hm}^{2}\right)\right)$. The soil erodibility in the cropland was significantly greater than those of grassland, woodland and shrubland $(P<0.05)$. However, no significant difference in soil erodibility was found between grassland and woodland or between woodland and shrubland. As shown in Figure 2b, significant differences in soil erodibility were found among the different sites. Compared with cropland, soil erodibility of the 
restored lands (grassland, woodland and shrubland) decreased, ranging from $3.99 \%$ to $21.43 \%$. Among the 5 sites in the grassland, the soil erodibility of GAC was highest $(0.0331$ $\left.\left(\mathrm{t} \cdot \mathrm{hm}^{2} \cdot \mathrm{h}\right) /\left(\mathrm{MJ} \cdot \mathrm{mm} \cdot \mathrm{hm}^{2}\right)\right)$, followed by GA $\left(0.0329\left(\mathrm{t} \cdot \mathrm{hm}^{2} \cdot \mathrm{h}\right) /\left(\mathrm{MJ} \cdot \mathrm{mm} \cdot \mathrm{hm}^{2}\right)\right)$, GC $(0.0321$ $\left.\left(\mathrm{t} \cdot \mathrm{hm}^{2} \cdot \mathrm{h}\right) /\left(\mathrm{MJ} \cdot \mathrm{mm} \cdot \mathrm{hm}^{2}\right)\right), \quad$ GCC $\left(0.0305 \quad\left(\mathrm{t} \cdot \mathrm{hm}^{2} \cdot \mathrm{h}\right) /\left(\mathrm{MJ} \cdot \mathrm{mm} \cdot \mathrm{hm}^{2}\right)\right)$, and GCV $(0.0271$ $\left.\left(\mathrm{t} \cdot \mathrm{hm}^{2} \cdot \mathrm{h}\right) /\left(\mathrm{MJ} \cdot \mathrm{mm} \cdot \mathrm{hm}^{2}\right)\right)$. The soil erodibility of GC, GCC and GCV were significantly lower than that of $\mathrm{CZ}(P<0.05)$, whereas no significant difference was found among CZ, GAC, and GA. For the 3 sites in the woodland, the soil erodibility of WP was $8.15 \%$ and $7.30 \%$ higher than those of WO and WSO, respectively $(P<0.05)$. The soil erodibility of SR was significantly lower than those of the other sites, except for GCV, WO, and WSO.
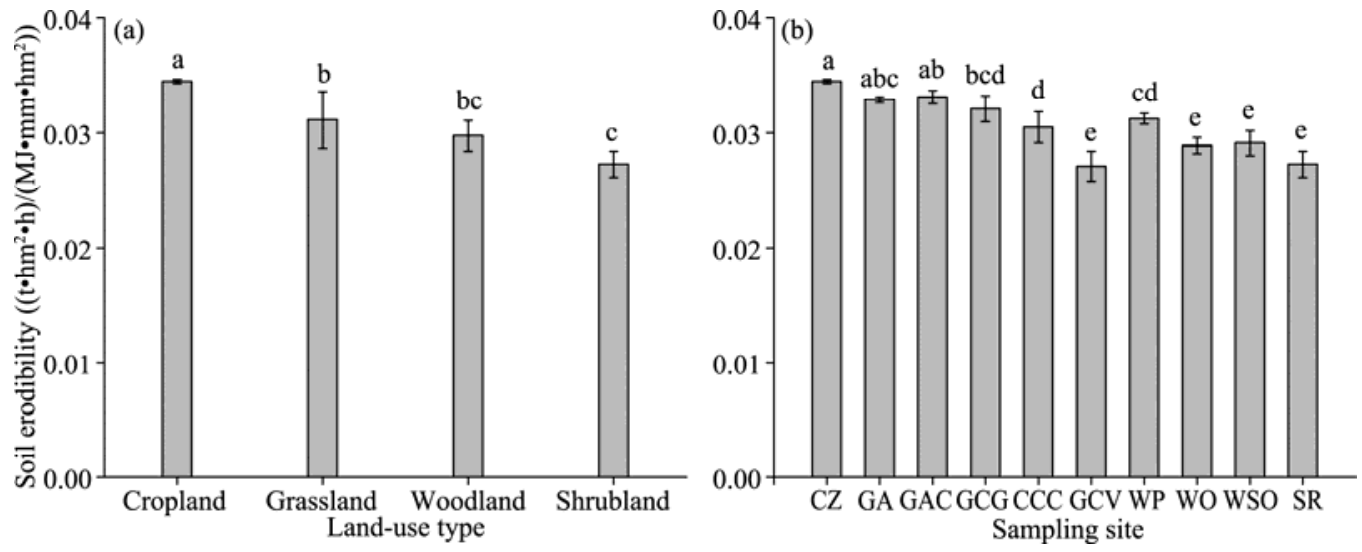

Fig. 2 Soil erodibility in different land-use types (a) and sampling sites (b). Different letters indicate significant differences among the land-use types or sampling sites at $P<0.05$ level based on Duncan's test. Bars denote standard errors.

The variation in soil erodibility with restoration time is shown in Figure 3. As expected, soil erodibility was greatly affected by restoration time. Furthermore, the natural restored grassland, the planted woodland and shrubland exhibited two different successional processes (Fig. 3). For the natural restored grassland chronosequence, soil erodibility linearly decreased with restoration time $\left(R^{2}=0.896, P<0.01\right)$. For the planted woodland and shrubland chronosequences, soil erodibility also decreased linearly with restoration time $\left(R^{2}=0.974, P<0.01\right)$, but more slowly than that of grassland, indicating that natural restored grassland can reduce soil erodibility more quickly than planted woodland or shrubland.

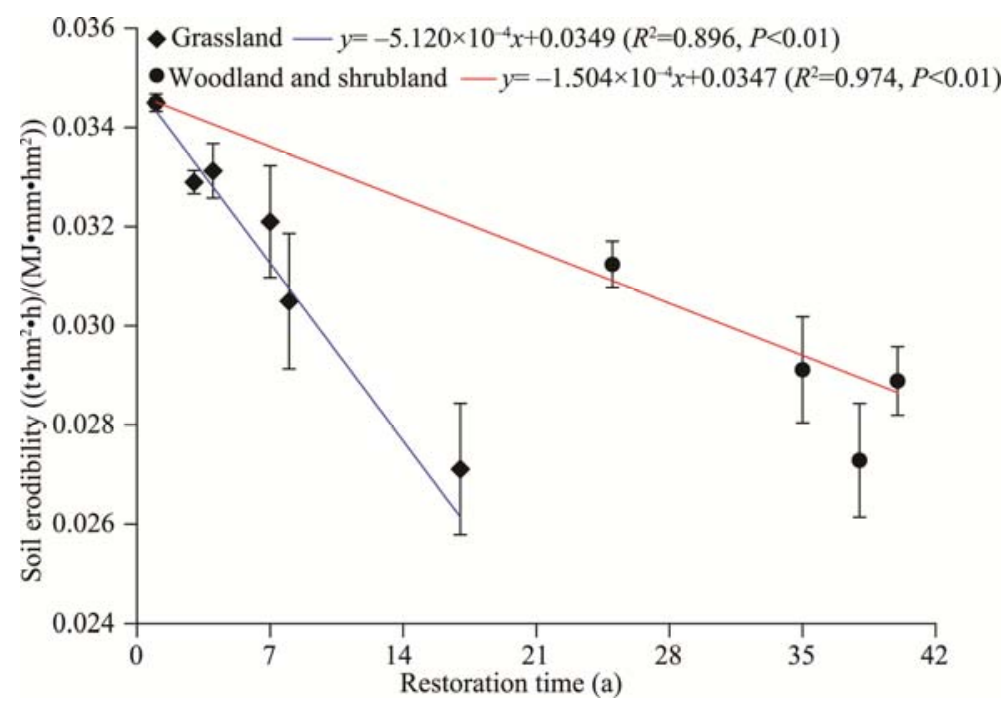

Fig. 3 Variation in soil erodibility with restoration time for the grassland, woodland and shrubland. Bars denote standard errors. 


\subsection{Relationships of soil erodibility, soil properties and root characteristics}

Correlation analysis showed soil erodibility to be positively correlated with soil clay content, silt content and disintegration rate $(P<0.01)$, but negatively correlated with soil sand content, saturated hydraulic conductivity, organic matter content and mean weight diameter of water-stable aggregate $(P<0.01$; Table 4$)$. In addition, no significant correlation was detected between soil erodibility and soil bulk density and between soil erodibility and soil total porosity. We found that the SOM content had the greatest correlation with soil erodibility. Regression analysis showed that soil erodibility linearly increased with increases in soil clay and silt contents (Figs. 4a and b), but linearly decreased with increases in sand content (Fig. 4c). Moreover, soil erodibility increased with soil disintegration rate as a power function (Fig. 4d), while it significantly decreased with soil saturated hydraulic conductivity (Fig. 4e), SOM content (Fig. 4f) and mean weight diameter of water-stable aggregate (Fig. $4 \mathrm{~g}$ ) as a linear function. These results indicate that soil erodibility is significantly affected by soil properties, except for soil bulk density and soil total porosity.

Table 4 Correlation coefficients among restoration time, soil properties, root characteristics and soil erodibility

\begin{tabular}{|c|c|c|c|c|c|c|c|c|c|c|c|c|c|c|c|}
\hline & $\mathrm{RT}$ & CLA & SIL & SAN & SBD & STP & SDR & SHC & SOM & MWD & RAD & RLD & RSAD & RBD & $K$ \\
\hline CLA & $-0.734^{* *}$ & 1.000 & & & & & & & & & & & & & \\
\hline SIL & $-0.474^{* *}$ & 0.296 & 1.000 & & & & & & & & & & & & \\
\hline SAN & $0.720^{* *}$ & $-0.731^{* *}$ & $-0.868^{* *}$ & 1.000 & & & & & & & & & & & \\
\hline SBD & -0.005 & 0.018 & $0.409^{*}$ & -0.301 & 1.000 & & & & & & & & & & \\
\hline STP & 0.003 & -0.014 & $-0.409^{*}$ & 0.300 & $-0.990^{* *}$ & 1.000 & & & & & & & & & \\
\hline SDR & $-0.740^{* *}$ & $0.604^{* *}$ & $0.596^{* *}$ & $-0.739^{* *}$ & 0.077 & -0.075 & 1.000 & & & & & & & & \\
\hline SHC & $0.552^{* *}$ & -0.237 & $-0.553^{* *}$ & $0.518^{* *}$ & $-0.429^{*}$ & $0.427^{*}$ & $-0.480^{* *}$ & 1.000 & & & & & & & \\
\hline SOM & $0.715^{* *}$ & $-0.564^{* *}$ & $-0.746^{* *}$ & $0.826^{* *}$ & -0.116 & 0.114 & $-0.840^{* *}$ & $0.517^{* *}$ & 1.000 & & & & & & \\
\hline MWD & D $0.728^{* *}$ & $-0.495^{* *}$ & $-0.591^{* *}$ & $0.679^{* *}$ & -0.157 & 0.154 & $-0.688^{* *}$ & $0.421^{*}$ & $0.770^{* *}$ & 1.000 & & & & & \\
\hline RAD & $0.569^{* *}$ & $-0.406^{*}$ & $-0.404^{*}$ & $0.500^{* *}$ & 0.025 & -0.026 & $-0.651^{* *}$ & 0.213 & $0.737^{* *}$ & $0.608^{* *}$ & 1.000 & & & & \\
\hline RLD & $0.771^{* *}$ & $-0.565^{* *}$ & $-0.553^{* *}$ & $0.689^{* *}$ & -0.052 & 0.049 & $-0.745^{* *}$ & $0.416^{*}$ & $0.845^{* *}$ & $0.863^{* *}$ & $0.793^{* *}$ & 1.000 & & & \\
\hline RASD & D $0.669^{* *}$ & $-0.410^{*}$ & $-0.516^{* *}$ & $0.581^{* *}$ & -0.019 & 0.016 & $-0.749^{* *}$ & 0.345 & $0.826^{* *}$ & $0.766^{* *}$ & $0.880^{* *}$ & $0.932^{* *}$ & 1.000 & & \\
\hline RBD & 0.140 & 0.044 & -0.262 & 0.164 & -0.050 & 0.050 & $-0.375^{*}$ & 0.224 & $0.485^{* *}$ & 0.285 & $0.639^{* *}$ & 0.355 & $0.521^{* *}$ & 1.000 & \\
\hline K & $-0.746^{* *}$ & $0.569^{* *}$ & $0.847^{* *}$ & $-0.901^{* *}$ & 0.246 & -0.244 & $0.794^{* *}$ & $-0.586^{* *}$ & $-0.944^{* *}$ & $-0.781^{* *}$ & $-0.645^{* *}$ & $-0.835^{* *}$ & $-0.772^{* *}$ & $-0.361^{*}$ & 1.000 \\
\hline
\end{tabular}

In addition, Table 4 shows that soil erodibility was significantly negatively correlated with the root average diameter, root length density, root surface area density and root biomass density. Moreover, soil erodibility decreased with root average diameter as a linear function (Fig. 5a). Additionally, the correlation coefficients of soil erodibility with root length density and root surface area density were higher than that between soil erodibility and root biomass density (Table 4). Linear functions well described the relationships of soil erodibility with root length density and root surface area density, with $R^{2}$ values of 0.688 and 0.592 , respectively (Figs. $5 \mathrm{~b}$ and c). However, a weak logarithmic function was found between soil erodibility and root biomass density, with $R^{2}$ of 0.315 (Fig. 5d). Comparatively, root length density had a greater effect on soil erodibility than root average diameter, root surface area density and root biomass density did.

\section{Discussion}

\subsection{Effects of vegetation restoration on soil properties}

Estimation of the effects of vegetation restoration on soil properties can help in determining the 


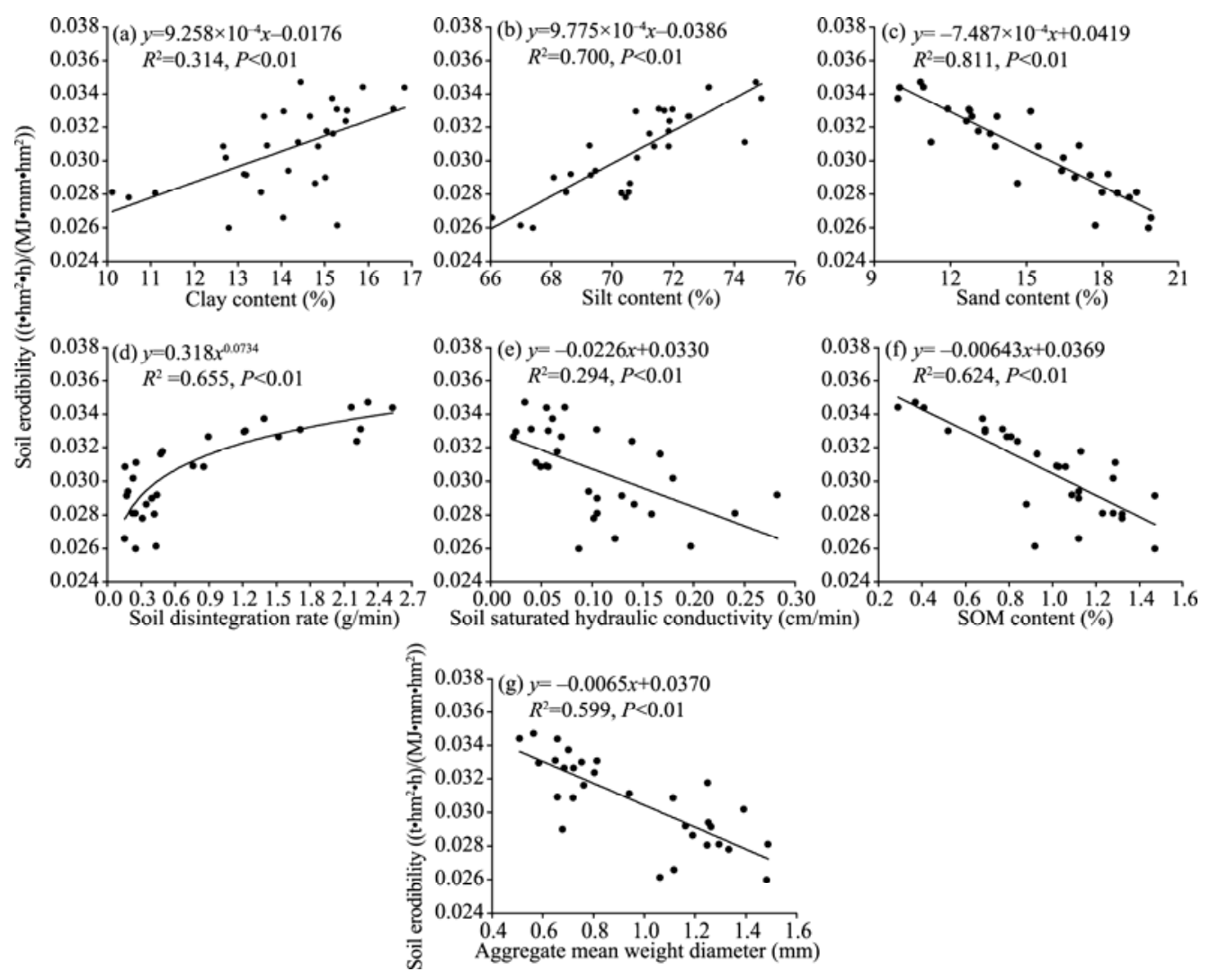

Fig. 4 Relationships between soil erodibility and soil properties. (a), clay content; (b), silt content; (c), sand content; (d), soil disintegration rate; (e), soil saturated hydraulic conductivity; (f), SOM content; (g), mean weight diameter of water-stable aggregate. SOM, soil organic matter.
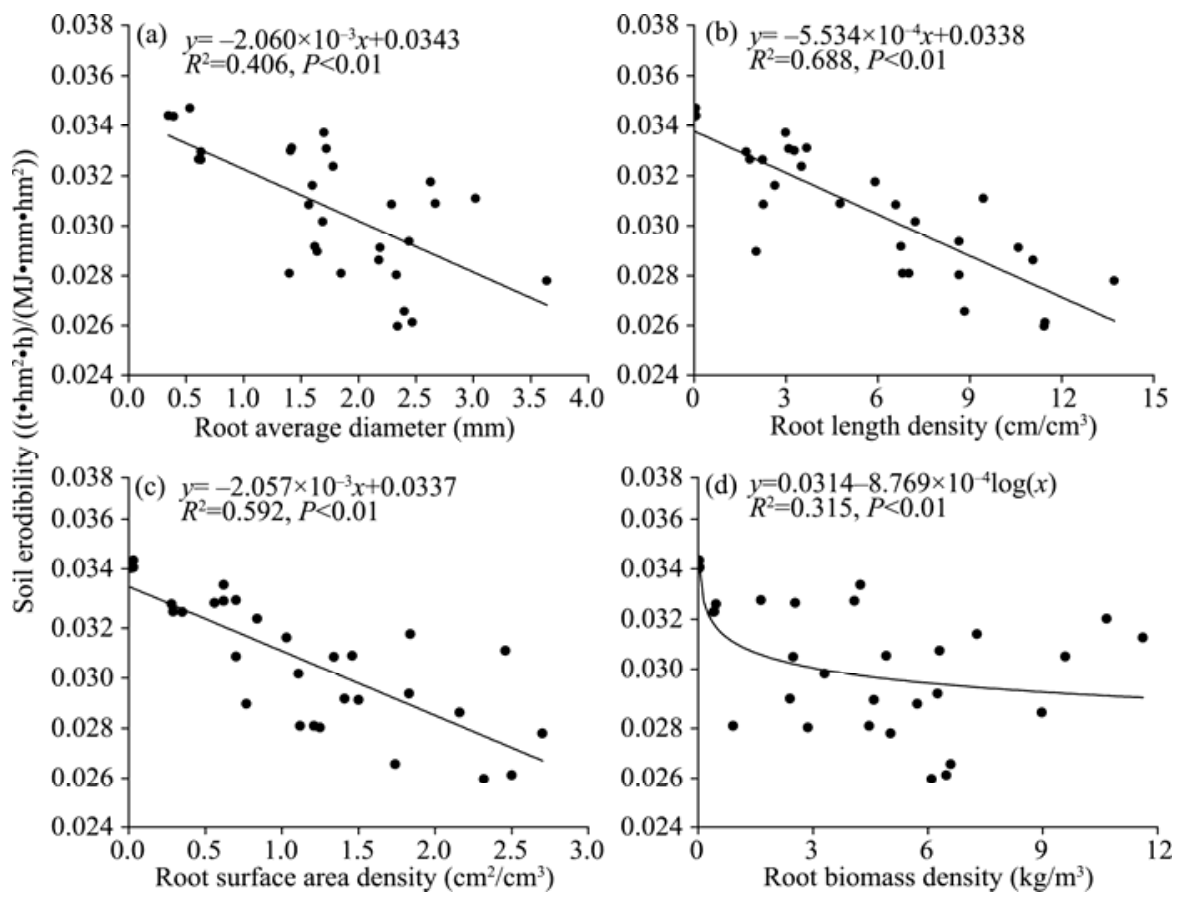

Fig. 5 Relationships between soil erodibility and root parameters. (a), root average diameter; (b), root length density; (c), root surface area density; (d), root biomass density. 
vulnerability of land to degradation (Jiao et al., 2011; Wang et al., 2012). Our results showed that the soil sand content, soil saturated hydraulic conductivity, SOM content and water-stable aggregate stability increased during vegetation restoration and that the soil clay and silt contents and soil disintegration rate decreased with restoration time (Tables 2-4). These results are consistent with previous findings of the positive effects of vegetation restoration on soil properties. For example, Wang et al. (2014) demonstrated that the soil sand content of restored lands was 1.53- to 1.93 -fold greater than that of slope farmland, whereas the soil silt and clay contents were $2.6 \%$ to $11.4 \%$ and $10.7 \%$ to $33.2 \%$ lower than those in the slope cropland, respectively. Natural vegetation restoration significantly increased soil water-stable aggregate stability and soil saturated hydraulic conductivity at the $0-20 \mathrm{~cm}$ depth in abandoned farmland (Li and Shao, 2006) and also significantly enhanced soil structural stability and the organic matter content (Jiao et al., 2011). However, it decreased the soil disintegration rate (Li et al., 2013). Improvements of soil properties by vegetation restoration can be attributed to the accumulation of fresh plant residues and root exudates in the surface soil and to roots and decomposed root residues in subsurface soil (Zhu et al., 2010; Zhao et al., 2013). These substances can be directly transformed into SOM and therefore provide energy/carbon sources and nutrients for soil microorganisms (Jastrow, 1996; Six et al., 2004), further promoting the formation of water-stable aggregates (Six et al., 2000; Kong et al., 2005). This fact may explain the significant correlations among the restoration time, mean weight diameter of water-stable aggregate, soil disintegration rate, saturated soil hydraulic conductivity and SOM content (Table 4). In contrast, no significant correlations were found among soil bulk density, soil total porosity and restoration time (Table 4), though soil bulk density values of sites in the restored lands were higher than that in $\mathrm{CZ}$ and soil total porosity values were lower than that in CZ, except for GCC and GCV (Table 2). These results are not consistent with those of Jiao et al. (2011), Li and Shao (2006) and Zhao et al. (2013), who reported that vegetation restoration significantly decreased soil bulk density and increased soil total porosity. Such differences in soil bulk density and soil total porosity might be related to human activities (Li and Shao, 2003; Zhang et al., 2009). The topsoil structure in the cropland is usually unstable and can easily be negatively influenced by human tillage activities (planting, hoeing and plowing), and grazing activities in restored lands can increase topsoil bulk density. Thus, soil bulk density of cropland is lower than that of restored lands (Zhang et al., 2009; Zhou et al., 2010).

\subsection{Effects of vegetation restoration on soil erodibility}

According to our results, the soil erodibility values of restored lands were significantly lower than that of cropland $(P<0.05)$, which were consistent with the conclusions of Singh and Khera (2008), Chen et al. (2013), and Deng et al. (2016). Chen et al. (2013) found reduced soil erodibility in 3 hedgerow patterns compared with cropland. We also found large differences in soil erodibility among different vegetation restoration patterns (Fig. 2). Variation in soil erodibility among different vegetation patterns can benefit the planning of soil and water conservation measures by targeting efforts to reduce soil erosion (Zhu et al., 2010; Li et al., 2015). Grassland (GCV) and shrubland (SR) can be considered as the best patterns of vegetation restoration to improve soil anti-erodibility of gully heads. In addition, as expected, soil erodibility decreased significantly as the time of abandonment increased $(P<0.01$; Fig. 3). Although Zhu et al. (2010) found a similar trend in variation of soil erodibility with time of abandonment, Wang et al. (2013) reported that soil erodibility of natural abandoned cropland decreased gradually with restoration time and tended to stabilize by 28 years after abandonment. The regression functions shown in Figure 3 indicate that the time required for soil erodibility of cropland to return to the levels of grassland, woodland and shrubland was approximately 7.3, 33.0 and 49.3 years, respectively. These results show that grassland can enhance soil anti-erodibility more quickly than woodland and shrubland, and also indirectly demonstrate that although vegetation destruction is a short-term process, restoration of soil anti-erodibility is a long-term process in different land-use types (Zhu et al., 2010).

Previous studies reported that different plant species were characterized by different root 
architectures. The distribution of the root architectures in soil layers could cause changes in soil properties and root characteristics (e.g., De Baets et al., 2007; Li et al., 2015), which would induce changes in soil erodibility (De Baets et al., 2006; Wang et al., 2013). Zhu et al. (2010) and $\mathrm{Wu}$ et al. (2016) concluded that conversions of cropland to grassland, woodland and shrubland can lead to increases in SOM. The SOM is accompanied by greater abundance of substances that could help to bind soil particles together in an organic-mineral complex, and thus could increase soil aggregation and soil anti-erodibility. This conclusion may explained the difference in soil erodibility among different land-use types, vegetation restoration patterns and restoration times (Figs. 2 and 3). Our study revealed that soil properties and root characteristics are closely associated with soil erodibility (Table 4; Figs. 4 and 5). Conversely, Li et al. (2015) found no significant correlation between soil erodibility and clay or sand content. Moreover, soil bulk density and soil total porosity had no significant effect on soil erodibility, which was inconsistent with previous studies (e.g., Knapen et al., 2007; Zhu et al., 2010). This difference was most likely related to human tillage and grazing activities (Li and Shao, 2003; Zhang et al., 2009). Many previous studies have also reported that root systems have negative influences on soil erodibility (Gyssels et al., 2006; De Baets and Poesen, 2010; Zhang et al., 2013). However, our results showed an opposite trend as those of Yu et al. (2014), who found soil erodibility to be positively correlated with root average diameter of millet and negatively correlated with those of maize, soybean and potato. In the present study, the relationship between soil erodibility and root average diameter was derived from root data of 4 land-use types (cropland, woodland, grassland and shrubland) and various vegetation types with different tap and fibrous root architectures. These differences again revealed that soil erodibility is greatly influenced by vegetation type, root architecture and land use (Yu et al., 2014; Li et al., 2015). The close relationships of soil erodibility with soil properties and root characteristics also suggest that improvements of soil properties and accumulation of roots in soil during vegetation restoration can significantly reduce soil erodibility.

\section{Conclusions}

In this study, we analyzed the effect of vegetation restoration on soil properties and erodibility of gully heads in a gully region of the Loess Plateau. Our study revealed that vegetation restoration greatly increased soil texture coarseness, bulk density, saturated hydraulic conductivity, organic matter content and water-stable aggregate ability, and decreased soil total porosity, disintegration rate and erodibility. Compared with cropland, soil erodibility in restored lands (grassland, woodland and shrubland) decreased by $3.99 \%-21.43 \%$. The restoration pattern of Cleistogenes caespitosa K. and Artemisia sacrorum L. in the grassland showed the lowest soil erodibility and can be considered as the optimal vegetation restoration pattern for improving soil anti-erodibility of the gully heads. Soil particle size distribution, disintegration rate, saturated hydraulic conductivity, water-stable aggregate stability, organic matter content and root characteristics had significant effects on soil erodibility. However, the effect of restoration time on soil erodibility differed among the natural restored grassland, and the planted woodland and shrubland. The negative linear change in soil erodibility of the grassland with restoration time was faster than those of the woodland and shrubland. The results also indicate that although vegetation destruction is a short-term process, it would be a long-term (8-50 years) process for the soil erodibility of cropland reducing to the levels of grassland, woodland and shrubland.

\section{Acknowledgements}

This study was supported by the National Natural Science Foundation of China (41571275), the Western Action Plan Project of the Chinese Academy of Sciences (KZCX-XB3-13) and the Major Program of the National Natural Science Foundation of China (41790444/D0214). The authors thank the anonymous reviewers for their insightful comments on the manuscript. 


\section{References}

An S S, Huang Y M, Zheng F L. 2009. Evaluation of soil microbial indices along a revegetation chronosequence in grassland soils on the Loess Plateau, Northwest China. Applied Soil Ecology, 41(3): 286-292.

Barthès B, Roose E. 2002. Aggregate stability as an indicator of soil susceptibility to runoff and erosion; validation at several levels. Catena, 47(2): 133-149.

Bennett S J, Alonso C V. 2006. Turbulent flow and bed pressure within headcut scour holes due to plane reattached jets. Journal of Hydraulic Research, 44(4): 510-521.

Bissonnais Y L. 1996. Aggregate stability and assessment of soil crustability and erodibility: I. Theory and methodology. European Journal of Soil Science, 47(4): 425-437.

Chen J J, He B H, Wang X Y, et al. 2013. The effects of herba andrographitis hedgerows on soil erodibility and fractal features on sloping cropland in the Three Gorges Reservoir Area. Environmental Science and Pollution Research, 20(10): 7063-7070.

De Baets S, Poesen J, Gyssels G, et al. 2006. Effects of grass roots on the erodibility of topsoils during concentrated flow. Geomorphology, 76(1-2): 54-67.

De Baets S, Poesen J, Knapen A, et al. 2007. Impact of root architecture on the erosion-reducing potential of roots during concentrated flow. Earth Surface Processes and Landforms, 32(9): 1323-1345.

De Baets S, Poesen J. 2010. Empirical models for predicting the erosion-reducing effects of plant roots during concentrated flow erosion. Geomorphology, 118(3-4): 425-432.

Deng Y S, Xia D, Cai C F, et al. 2016. Effects of land uses on soil physic-chemical properties and erodibility in collapsing-gully alluvial fan of Anxi County, China. Journal of Integrative Agriculture, 15(8): 1863-1873.

Frankl A, Poesen J, Deckers J, et al. 2012. Gully head retreat rates in the semi-arid highlands of Northern Ethiopia. Geomorphology, 173-174: 185-195.

Gómez-Gutiérrez Á, Schnabel S, Berenguer-Sempere F, et al. 2014. Using 3D photo-reconstruction methods to estimate gully headcut erosion. Catena, 120: 91-101.

Gyssels G, Poesen J, Bochet E, et al. 2005. Impact of plant roots on the resistance of soils to erosion by water: a review. Progress in Physical Geography, 29(2): 189-217.

Gyssels G, Poesen J, Liu G B, et al. 2006. Effects of cereal roots on detachment rates of single- and double-drilled topsoils during concentrated flow. European Journal of Soil Science, 57(3): 381-391.

$\mathrm{Hu}$ W, Shao M A, Wang Q J, et al. 2009. Temporal changes of soil hydraulic properties under different land uses. Geoderma, 149(3-4): 355-366.

Huang Z L, Chen L D, Fu B J, et al. 2010. The relative efficiency of four representative cropland conversions in reducing water erosion: evidence from long-term plots in the Loess hilly area, China. Land Degradation \& Development, 17(6): 615-627.

Jastrow J D. 1996. Soil aggregate formation and the accrual of particulate and mineral-associated organic matter. Soil Biology and Biochemistry, 28(4-5): 665-676.

Jiao F, Wen Z M, An S S. 2011. Changes in soil properties across a chronosequence of vegetation restoration on the Loess Plateau of China. Catena, 86(2): 110-116.

Knapen A, Poesen J, Govers G, et al. 2007. Resistance of soils to concentrated flow erosion: a review. Earth-Science Reviews, 80(1-2): 75-109.

Knapen A, Poesen J, Govers G, et al. 2008. The effect of conservation tillage on runoff erosivity and soil erodibility during concentrated flow. Hydrological Processes, 22(10): 1497-1508

Kong A Y Y, Six J, Bryant D C, et al. 2005. The relationship between carbon input, aggregation, and soil organic carbon stabilization in sustainable cropping systems. Soil Science Society of America Journal, 69(6): 1078-1085.

Li Y Y, Shao M A. 2003. Natural succession and evolution of structural characteristics of forest community in Ziwuling area on the Loess Plateau. Acta Botanica Boreali-Occidentalia Sinica, 23(5): 693-699. (in Chinese)

Li Y Y, Shao M A. 2006. Change of soil physical properties under long-term natural vegetation restoration in the Loess Plateau of China. Journal of Arid Environments. 64(1): 77-96.

Li Q, Liu G B, Xu M X, 2013. Soil anti-scouribility and its related physical properties on abandoned land in the hilly Loess Plateau. Transactions of the Chinese Society of Agricultural Engineering, 29(10): 153-159. (in Chinese)

Li Q, Liu G B, Zhang Z, et al. 2015. Effect of root architecture on structural stability and erodibility of topsoils during concentrated flow in hilly Loess Plateau. Chinese Geographical Science, 25(6): 757-764.

Li Z W, Zhang G H, Geng R, et al. 2015. Rill erodibility as influenced by soil and land use in a small watershed of the Loess Plateau, China. Biosystems Engineering, 129: 248-257.

Mamo M, Bubenzer G D. 2001a. Detachment rate, soil erodibility, and soil strength as influenced by living plant roots: Part I. 
Laboratory study. American Society of Agricultural Engineers, 44: 1167-1174.

Mamo M, Bubenzer G D. 2001b. Detachment rate, soil erodibility and soil strength as influenced by living plant roots: Part II. Field study. American Society of Agricultural Engineers, 44: 1175-1181.

Marzolff I, Poesen J. 2009. The potential of 3D gully monitoring with GIS using high-resolution aerial photography and a digital photogrammetry system. Geomorphology, 111(1-2): 48-60.

Parwada C, Tol J V. 2016. Soil properties influencing erodibility of soils in the Ntabelanga area, Eastern Cape province, South Africa. Acta Agriculturae Scandinavica, Section B-Soil \& Plant Science, 67(1): 67-76.

Schwartz R C, Everett S R, Unger P W. 2003. Soil hydraulic properties of cropland compared with reestablished and native grassland. Geoderma, 116(1-2): 47-60.

Sheridan G J, So H B, Loch R J, et al. 2000. Estimation of erosion model erodibility parameters from media properties. Australian Journal of Soil Research, 38(2): 265-284.

Singh M J, Khera K L. 2008. Soil erodibility indices under different land uses in lower shiwaliks. Tropical Ecology, 49(2): 113-119.

Six J, Paustian K, Elliott E T, et al. 2000. Soil structure and organic matter: I. distribution of aggregate-size classes and aggregate-associated carbon. Soil Science Society of America Journal, 64(2): 681-689.

Six J, Bossuyt H, Degryze S, et al. 2004. A history of research on the link between (micro) aggregates, soil biota, and soil organic matter dynamics. Soil and Tillage Research, 79(1): 7-31.

Vanmaercke M, Poesen J, Mele B V, et al. 2016. How fast do gully headcuts retreat? Earth-Science Reviews, 154: 336-355.

Vannoppen W, Vanmaercke M, De Baets S, et al. 2015. A review of the mechanical effects of plant roots on concentrated flow erosion rates. Earth-Science Reviews, 150: 666-678.

Wang L, Mu Y, Zhang Q F, et al. 2012. Effects of vegetation restoration on soil physical properties in the wind-water erosion region of the Northern Loess Plateau of China. Clean Soil Air Water, 40(1): 7-15.

Wang B, Zhang G H, Shi Y Y, et al. 2013. Effect of natural restoration time of abandoned farmland on soil detachment by overland flow in the Loess Plateau of China. Earth Surface Processes and Landforms, 38(14): 1725-1734.

Wang B, Zhang G H, Shi Y Y, et al. 2014. Soil detachment by overland flow under different vegetation restoration models in the Loess Plateau of China. Catena, 116(5): 51-59.

Wang G Q, Fang Q Q, Wu B B, et al. 2015. Relationship between soil erodibility and modeled infiltration rate in different soils. Journal of Hydrology, 528: 408-418.

Williams J R, Arnold J G. 1997. A system of erosion-sediment yield models. Soil Technology, 11(1): 43-55.

Wu G L, Liu Y, Fang N F, et al. 2016. Soil physical properties response to grassland conversion from cropland on the semi arid area. Ecohydrology, 9(8): 1471-1479.

Yu Y C, Zhang G H, Geng R, et al. 2014. Temporal variation in soil detachment capacity by overland flow under four typical crops in the Loess Plateau of China. Biosystems Engineering, 122(3): 139-148.

Zhang G H, Tang M K, Zhang X C. 2009. Temporal variation in soil detachment under different land uses in the Loess Plateau of China. Earth Surface Processes and Landforms, 34(9): 1302-1309.

Zhang G H, Tang K M, Ren Z, et al. 2013. Impact of grass root mass density on soil detachment capacity by concentrated flow on steep slopes. Transactions of the ASABE, 56(3): 927-934.

Zhang Z H, Li X Y, Jiang Z Y, et al. 2013. Changes in some soil properties induced by re-conversion of cropland into grassland in the semiarid steppe zone of Inner Mongolia, China. Plant and Soil, 373(1-2): 89-106.

Zhao Y, Wu P, Zhao S, Feng H. 2013. Variation of soil infiltrability across a 79-year chronosequence of naturally restored grassland on the Loess Plateau, China. Journal of Hydrology, 504(22): 94-103.

Zhou Z C, Gan Z T, Shangguan Z P, et al. 2010. Effects of grazing on soil physical properties and soil erodibility in semiarid grassland of the northern Loess Plateau (China). Catena, 82(2): 87-91.

Zhu B B, Li Z B, Li P, et al. 2010. Soil erodibility, microbial biomass, and physical-chemical property changes during long-term natural vegetation restoration: a case study in the Loess Plateau, China. Ecological Research, 25(3): 531-541. 